\title{
Magnolia grandiflora L. shows better responses to drought than Magnolia $\times$ soulangeana in urban environment
}

\author{
Erna Vastag (1-2), \\ Saša Orlović (2), \\ Alena Konôpková( ${ }^{(3)}$, \\ Daniel Kurjak ${ }^{(3)}$, \\ Claudia Cocozza ${ }^{(4)}$, \\ Eva Pšidová (5), \\ Katharina Lapin ${ }^{(6)}$, \\ Lazar Kesić (2), \\ Srđan Stojnić (2)
}

(1) Department of Fruit Growing, Viticulture, Horticulture and Landscape Architecture, Faculty of Agriculture, University of Novi Sad, Trg Dositeja Obradovića 8, 21000 Novi Sad (Serbia); (2) Institute of Lowland Forestry and Environment, University of Novi Sad, Antona Cehova 13d, 21000 Novi Sad (Serbia); (3) Department of Integrated Forest and Landscape Protection, Faculty of Forestry, Technical University in Zvolen, T. G. Masaryka 24, 96001 Zvolen (Slovakia); (4) Department of Agriculture, Food, Environment and Forestry, University of Florence, 50145 Florence (Italy); (5) Department of Plant Ecophysiology, Institute of Forest Ecology, Slovak Academy of Sciences, Štúrova 2, 96053 Zvolen (Slovakia); (6) Department of Forest Growth and Silviculture, Protection Forest and Natural Forest Reserves, Federal Research and Training Centre for Forest, Natural Hazards and Landscape, Seckendorff-Gudent-Weg 8, 1131 Vienna (Austria)

\section{@ Erna Vastag (erna.vastag@uns.ac.rs)}

Received: Jul 21, 2020 - Accepted: Oct 01, 2020

Citation: Vastag E, Orlović S, Konôpková A, Kurjak D, Cocozza C, Pšidová E, Lapin K, Kesić L, Stojnić S (2020). Magnolia grandiflora $\mathrm{L}$. shows better responses to drought than Magnolia $\times$ soulangeana in urban environment. iForest 13: 575-583. doi: 10.3832/ifor3596-013 [online 2020-1207]

Communicated by: Werther Guidi Nissim

Drought tolerance is becoming an increasingly important criterion for the selection of tree species, especially in urban areas characterized by low water availability. Apart from drought tolerance, the introduction of non-native species should be considered for new planting programs under such conditions to enhance the resilience of urban forests. The present study is aimed at evaluating the in situ physiological responses of Magnolia grandiflora and Magnolia $\times$ soulangeana to severe drought that frequently occurs in urban environments in the Southeastern Europe. Transpiration rate, stomatal conductance, intercellular $\mathrm{CO}_{2}$ concentration, water-use efficiency and intrinsic water-use efficiency showed notable differences both between species and between the measured periods (wet and dry). Among the chlorophyll $a$ fluorescence parameters, effective photochemical quantum yield of PS II, quantum yield of lightinduced non-photochemical fluorescence quenching, quantum yield of nonregulated heat dissipation, fluorescence emission and index of susceptibility of leaves to light stress revealed significant differences both between the two species and the periods of measurements. The reduction of net photosynthesis in both magnolia species occurs as the result of non-stomatal limitation obtained by the reduction of electron transport rate coupled with simultaneous increase in intercellular $\mathrm{CO}_{2}$ concentration. Moreover, M. grandiflora was the species less vulnerable to water shortage conditions, while $M$. soulangeana exhibited a photosynthetic capacity sensitive to drought-induced stress. M. grandiflora can therefore be considered as a promising alternative to $M$. soulangeana for urban sites under the predicted climate change scenarios.

Keywords: Chlorophyll a Fluorescence, Drought, Leaf Gas Exchange, Photosynthesis, Urban Tree Selection

\section{Introduction}

Urban ecosystems pose multiple challenges for trees to cope with (Sjöman et al. 2018a). Among the various environmental factors occurring in urban settlements, drought was being recognized as one of the most frequent and threatening constraint, resulting from the combination of water deficit and high temperatures (Kleerekoper et al. 2012), thereby causing serious damages and a premature mortality of urban trees (Wang et al. 2019). Apart from directly influencing the tree by inhibiting its growth through reduced photosynthetic rates, drought has additional indirect impacts as well, e.g., by predisposing trees to pathogens (Dale \& Frank 2017) and pollutants (Cocozza et al. 2019).

The severity of the negative effects on plants is related to the intensity, duration, and course of progression of drought stress (Chaves et al. 2009). In plants subjected to mild to moderate drought, stomatal control is the major physiological mechanism preventing excessive water loss, causing an overall reduction of photosynthesis and consequently the inhibition of plant growth (Xu et al. 2010). Under more severe drought stress, metabolic and biochemical limitations may occur and re- duce $\mathrm{CO}_{2}$ assimilation rates; these processes include the inhibition of Rubisco enzyme activity, damage of chlorophyll or photosystems, and a decrease in the capacity to generate ATP (Changhai et al. 2010).

Under drought conditions, PSII photochemistry of plants can be affected, and parameters of chlorophyll a fluorescence were shown to be rapid, highly sensitive and non-destructive tool for detecting species, genotypes and provenances with tolerant or susceptible behavior (Cocozza et al. 2016, Vastag et al. 2020). While early phases of drought were observed to impose slight changes on PSII, more progressive drought was noted to cause a depletion of PSII core and inhibit electron transport chain from the donor side of PSII to PSI, indicating non-stomatal inhibition of photosynthesis (Giardi et al. 1996).

The responses of plants in such conditions have been observed to be speciesspecific (Sjöman et al. 2018b, Vastag et al. 2019) due to differences in leaf morphology and physiology. For example, a significant decrease in photosynthetic activity in Ginkgo biloba L. was detected, which resulted in higher sensitivity to drought compared to Fraxinus chinensis Roxb. (Wang et 
al. 2019). Furthermore, several studies have evidenced that provenances and species originating from drier climate perform better under drought condition (Pšidová et al. 2015, Wang et al. 2017). For instance, investigation of the drought tolerance of Quercus ilex L., Q. pubescens Willd., and Q. robur L., showed that the Mediterranean oak species, despite a reduction of light-saturated net photosynthesis (Cocozza et al. 2020), maintained higher photosynthetic activity compared to Central-European oak species (Früchtenicht et al. 2018).

In the South-East Europe the climate scenarios, according to the medium-high emission baseline (A1B - IPCC 2007), project an increase of average air temperature from $2.4{ }^{\circ} \mathrm{C}$ up to $3.4{ }^{\circ} \mathrm{C}$, along with a $30 \%$ reduction of average rainfall until the end of the $21^{\text {st }}$ century, and the negative impact of drought will very likely become even more heightened. Under such harsh conditions, the physiology of trees will be affected, and this, in turn, could further impact the broad range of benefits they provide for humans ranging from shading streets to carbon sequestration (Sjöman et al. 2018a). To mitigate the negative effects of climate change, the evaluation of drought tolerance of tree species should be mainly contemplated for the selection plantation in urban ecosystems (Vogt et al. 2017, Sjöman et al. 2018a). In this context, the introduction of non-native species should be considered in new planting programs, alongside the use of drought-tolerant autochthonous species, as it has been noted that high species diversity contributes to increasing resilience and reducing the maintenance requirements of urban forests under abiotic and biotic challenges (Kendal et al. 2014).
The Magnolia genus of the Magnoliaceae family includes 224 ornamental species (Grimshaw \& Bayton 2009), and its planting in urban areas has increased significantly over the past decade. In Southeast Europe, Magnolia $\times$ soulangeana Soul.-Bod., a deciduous hybrid of Magnolia denudata Desr. and Magnolia liliflora Desr., is a very common species in urban parks, while Magnolia grandiflora L., an evergreen species native to the southern United States (Cvjetićanin et al. 2016), is encountered less often. However, as the distribution of forest tree species is generally expected to shift northwards in response to climate warming (Parmesan 2006), a similar expansion of the distribution of $M$. grandiflora could be expected in the future, increasing its frequency in Southeast Europe as well.

As both of these species have a high ornamental value, most literature deals mainly with their aesthetic qualities (Cvjetićanin et al. 2016). However, the selection of tree species for urban ecosystems should include other important factors, such as the microclimatic conditions of the respective site and the physiological performance of the species concerning stress factors (Vogt et al. 2017). Notably, understanding the interaction between the physiology of plants and their surrounding environment is essential for establishing better management strategies to alleviate stress conditions for the species (Sjöman et al. 2018a), especially in urban areas where these stressors are even more amplified and combined. Despite the wide range of research possibilities posed in urban environments, the physiological performance of trees, including the Magnolia genus, remains scarcely explored and understood (Wang et al. 2019). To support tree selection for urban

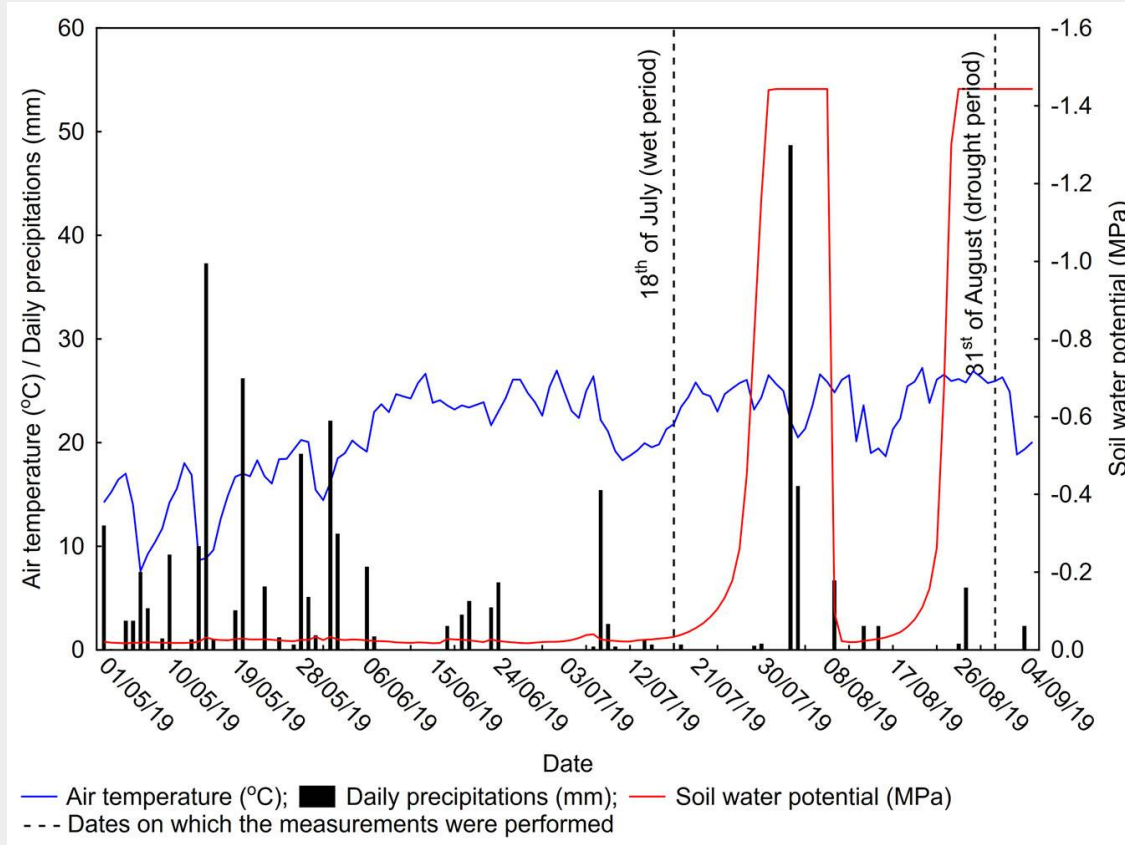

Fig. 1 - Mean daily air temperatures $\left({ }^{\circ} \mathrm{C}\right)$, total daily precipitation $(\mathrm{mm})$ and soil water potential (MPa) during the period from May 1 to September 4, 2019. areas in temperate climate and prevent mistakes in planning, which could result in high ecological and economic costs, the Citree database was developed (Vogt et al. 2017). However, Vogt et al. (2017) noted that additional field experiments should be included in the database, especially for aspects that have not been thoroughly investigated, such as the drought tolerance of species.

The present study was aimed to investigate the physiological response to naturally occurring severe drought of $M$. grandiflora and $M$. soulangeana planted in the urban area of Novi Sad, Serbia, South-East Europe. Tree responses were determined through accurate, reliable and non-invasive tools by estimating: (i) the photosynthetic function of plants under drought, to analyze the photosynthetic processes and detect water efficient and stress tolerant species (Wang et al. 2018); (ii) the effects of stress on photochemistry (Pšidová et al. 2018). We hypothesized that drought might (1) negatively affect leaf gas exchange and chlorophyll $a$ fluorescence in both magnolia species, by indicating tolerant and/or vulnerable drought behavior, (2) induce the non-stomatal regulations with consequent inhibition of net photosynthesis, and (3) less affect the photosynthetic performance of a species from drier climate than of a more humid site.

\section{Material and methods}

\section{Study area and species}

The present study was conducted in the urban green space of Novi Sad, the second largest city of Serbia $\left(45^{\circ} 15^{\prime} 10^{\prime \prime} \mathrm{N}, 19^{\circ} 50^{\prime}\right.$ $53^{\prime \prime} \mathrm{E}$ ), characterized as a pocket park (Rakhshandehroo \& Yusof 2014). At the studied locality, ten adult $M$. grandiflora $L$. and $M$. soulangeana Soul.-Bod. trees were chosen for the evaluation of physiological responses. Tree selection was based on visual impression, namely all chosen trees were vigorous, without dying branches, insect infestation, or mechanical damage (Moser et al. 2016). M. grandiflora trees were planted in a single linear row alongside a walkway in direction of West-East with a planting space of $3 \mathrm{~m}$ between them. On the other hand, $M$. soulangeana trees were arranged in double linear rows alongside a walkway in direction of NorthSouth and a planting space of $4 \mathrm{~m}$. Both species were planted in a common green space covered with grass and in full sunlight. For assessing the in situ physiological status of the two magnolia species in urban environment, leaf gas exchange and chlorophyll a fluorescence parameters were measured in wet (18 ${ }^{\text {th }}$ of July 2019) and drought ( $31^{\text {th }}$ of August 2019) periods.

\section{Meteorological data}

Monitoring of mean air temperature $\left({ }^{\circ} \mathrm{C}\right)$ and daily precipitation $(\mathrm{mm})$ was carried out at the nearby meteorological station Rimski Šančevi $\left(45^{\circ} 20^{\prime} \mathrm{N}, 19^{\circ} 51^{\prime} \mathrm{E}\right.$, altitude 
84 m a.s.l.) from May 1 to September 4, 2019. The soil water potential (SWP) was measured using calibrated gypsum blocks (Delmhorst Inc., Towaco, NJ, USA) positioned at $50 \mathrm{~cm}$ soil depth, with measurements at $30 \mathrm{~s}$ intervals stored in a $\mathrm{Mi}$ croLog $\mathrm{SP}_{3}{ }^{\circledast}$ datalogger (EMS, Brno, Czech Republic).

The wet period measurement was performed on July 18, 2019 after 10 days of SWP values below -0.4 MPa and mean air temperatures ranging between $19.2^{\circ} \mathrm{C}$ and $22.2{ }^{\circ} \mathrm{C}$, with the maximum temperature never reaching $30{ }^{\circ} \mathrm{C}$. The drought period measurement was performed on the August 31, 2019 after six days of SWP values below -1.4 MPa and mean air temperatures between $25.8^{\circ} \mathrm{C}$ and $26.9^{\circ} \mathrm{C}$, with the maximum air temperature exceeding $30^{\circ} \mathrm{C}$ (characterized as severe drought period according to Liu et al. 2010 - Fig. 1).

\section{Leaf gas exchange measurement}

The measurements of net photosynthesis $\left(A, \mu \mathrm{mol} \mathrm{m} \mathrm{m}^{-2} \mathrm{~s}^{-1}\right)$, transpiration rate $(E, \mathrm{mmo}$ $\mathrm{m}^{-2} \mathrm{~s}^{-1}$ ), stomatal conductance (gs, mmol $\left.\mathrm{m}^{-2} \mathrm{~s}^{-1}\right)$, and intercellular $\mathrm{CO}_{2}$ concentration $\left(\mathrm{Ci}, \mu \mathrm{mol} \mathrm{mol}^{-1}\right)$ were taken using a CIRAS$3^{\oplus}$ portable photosynthesis system (PP Systems, Amesbury, MA, USA). In order to minimize differences in light exposure, ex posed, outward-facing leaves on exterior branches in the upper reaches of the trees were chosen. During the measurements, the photosynthetic active radiation (PAR) was set to $1000 \mu \mathrm{mol} \mathrm{m}^{-2} \mathrm{~s}^{-1}$ while humidity, temperature, and the concentration of $\mathrm{CO}_{2}$ depended on the ambient conditions of study site. Following leaf stabilization in the CIRAS-3 chamber, the abovementioned parameters were recorded from 9:00 a.m. to 11:00 a.m. Water use efficiency (WUE, $\left.\mu \mathrm{mol} \mathrm{mmol}{ }^{-1}\right)$ was computed as the ratio of A to $E$ (Farquhar \& Sharkey 1982), and intrinsic water-use efficiency (WUEi, $\mu \mathrm{mol}$ $\mathrm{mol}^{-1}$ ) was derived as the ratio of $A$ to gs (Flexas et al. 2013). The leaf gas exchange parameters were determined for all ten plants of each species, with measurements taken in the order of 5 specimens of $M$. grandiflora followed by five specimens of $M$. soulangeana, etc. The same leaves were subsequently used for assessing the pulse amplitude modulated chlorophyll $a$ fluorescence, with three replications per leaf.

\section{Pulse amplitude modulated (PAM)}

\section{fluorescence measurements}

The photosynthetic activity of PSII was measured using a PAM-2500 ${ }^{\circledR}$ portable chlorophyll fluorometer (Walz $\mathrm{GmbH}$, Effeltrich, Germany) between 9:00 and 11:00 a.m. Before taking the measurements, the selected leaves were dark-acclimated for 15 minutes using leaf clips. The rapid light curves (RLC) were derived using nine increasing actinic illumination steps (0, 144, 274, 477, 788, 1163, 1389, 2018, $2443 \mu \mathrm{mol} \mathrm{e}$ $\left.\mathrm{m}^{-2} \mathrm{~s}^{-1}\right)$. The duration of each actinic illumination step was $10 \mathrm{~s}$, and the steps were separated by a white saturating flash of
Tab. 1 - The studied computed pulse amplitude modulated fluorescence parameters.

\begin{tabular}{|c|c|c|}
\hline Abbrev. & Equation & Definition of the derived parameters \\
\hline$\Phi_{\mathrm{PS} \|}$ & $\mathrm{Fm} \mathrm{m}^{\prime}-\mathrm{Ft} / \mathrm{Fm}^{\prime}$ & $\begin{array}{l}\text { Effective photochemical quantum yield of PS II } \\
\text { (Genty et al. 1989) }\end{array}$ \\
\hline Y(NPQ) & $\mathrm{Ft} / \mathrm{Fm}^{\prime}-\mathrm{Ft} / \mathrm{Fm}$ & $\begin{array}{l}\text { Quantum yield of light-induced non-photochemical } \\
\text { fluorescence quenching (Genty et al. 1996) }\end{array}$ \\
\hline$Y(N O)$ & $\mathrm{Ft} / \mathrm{Fm}$ & $\begin{array}{l}\text { Quantum yield of non-regulated heat dissipation } \\
\text { and fluorescence emission (Genty et al. 1996) }\end{array}$ \\
\hline$(1-q P) / N P Q$ & $(1-q P) / N P Q$ & $\begin{array}{l}\text { Index of susceptibility of leaves to light stress } \\
\text { (Osmond 1994) }\end{array}$ \\
\hline$q \mathrm{P}$ & $\left(\mathrm{Fm}^{\prime}-\mathrm{Ft}\right) /\left(\mathrm{Fm}^{\prime}-\mathrm{Fo}^{\prime}\right)$ & $\begin{array}{l}\text { Coefficient of photochemical quenching (Schreiber } \\
\text { et al. } 1986 \text { as formulated by Van Kooten \& Snel } \\
\text { 1990) }\end{array}$ \\
\hline ETR & $\mathrm{PAR} \cdot 0.84 \cdot 0.5$ & Rate of electron transport (Genty et al. 1989) \\
\hline
\end{tabular}

$\sim 3000 \mu \mathrm{mol} \mathrm{m} \mathrm{m}^{-2} \mathrm{~s}^{-1}$ lasting $0.8 \mathrm{~s}$. In addition, lowing model was used (eqn. 1): the studied PAM fluorescence parameters were computed (Tab. 1). Rapid light-response curves of chlorophyll a fluorescence were constructed by plotting the $\Phi_{\text {PSII, }} \mathrm{Y}(\mathrm{NPQ}), \mathrm{Y}(\mathrm{NO}),(1-\mathrm{qP}) / \mathrm{NPQ}, \mathrm{qP}$ and ETR versus the increasing actinic irradiance (from 1 to $2443 \mu \mathrm{mol} \mathrm{e} \mathrm{m}^{-2} \mathrm{~s}^{-1}$ - Vastag et al. 2020). The RLCs were quantified as follows: (i) maximal electron transport rate ETRmax $\left(\mu \mathrm{mol} \mathrm{e} \mathrm{m}^{-2} \mathrm{~s}^{-1}\right)$ for RLC $\mathrm{C}_{\mathrm{ETR}}$; ETRmax was calculated automatically according to internal equation (Eilers \& Peeters 1988) and reflects the light-saturated capacity of the sample; (ii) the area below the curve for $\mathrm{RLC}_{\text {ФPSII }}$; (iii) the value records at high light intensity $\left(2443 \mu \mathrm{mol} \mathrm{e} \mathrm{e}^{-2} \mathrm{~m}^{-2} \mathrm{~s}^{-1}\right)$ for $\mathrm{RLC}_{\mathrm{NPQ}}$,

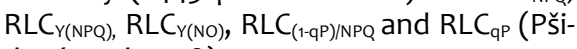
dová et al. 2018).

\section{Statistical analysis}

Statistical analysis of the leaf gas exchange and chlorophyll $a$ fluorescence parameters was conducted using Statistica v. 13 (TIBCO Software Inc. 2017) and R v. 3.6.3 ( $R$ Core Team, Austria). The differences between the two parameters were tested using two-way ANOVA, with the period (wet or dry) and species ( $M$. grandiflora and $M$. soulangeana) set as fixed factors. The fol-

$$
y_{i j k}=P_{i}+S_{j}+P_{i} \times S_{j}+\varepsilon_{i j k}
$$

where $y_{\mathrm{ijk}}$ represents the measured value of the phenotype, $P_{i}$ is the effect of the $i^{\text {th }}$ period, $S_{j}$ is the effect of the $j^{\text {th }}$ species, $P_{i} \times S_{j}$ is the interaction between the period and the species, and $\varepsilon_{\mathrm{ijk}}$ is the experimental error. Significant differences between the means were evaluated using Tukey's honestly significant difference (HSD) test with $P \leq 0.05$. Prior to the statistical analysis, the normality of data distribution was tested, with the transformation considered necessary for several parameters. All parameters were shown in the form of a bar diagram with means \pm standard errors drawn by Statistica v. 13 (TIBCO Software Inc. 2017).

\section{Results}

\section{Leaf gas exchange}

Leaf gas exchange parameters were significantly affected by environmental conditions in the considered period and site (Tab. 2). A, Ci, WUE, and WUEi significantly changed between species. Furthermore, the interaction of species $\times$ period exhibited a significant effect on all observed leaf

Tab. 2 - Results of two-way ANOVA showing the effects of species $(S)$, period (P), and their interaction $(S \times P)$ on the observed leaf gas exchange parameters. $(A)$ : net photosynthetic rate $\left(\mu \mathrm{mol} \mathrm{m} \mathrm{m}^{-2} \mathrm{~s}^{-1}\right)$; $(E)$ : rate of transpiration $\left(\mathrm{mmol} \mathrm{m} \mathrm{m}^{-2} \mathrm{~s}^{-1}\right)$; (gs); stomatal conductance ( $\left.\mathrm{mmol} \mathrm{m}^{-2} \mathrm{~s}^{-1}\right)$; $(\mathrm{Ci})$ : intercellular $\mathrm{CO}_{2}$ concentration ( $\left.\mu \mathrm{mol} \mathrm{mol} \mathrm{m}^{-1}\right)$; (WUE): water use efficiency $\left(\mu \mathrm{mol} \mathrm{mmol}^{-1}\right)$; (WUEi): intrinsic water use efficiency $\left(\mu \mathrm{mol} \mathrm{mol}^{-1}\right)$; (df): degrees of freedom.

\begin{tabular}{lcccccccc}
\hline $\begin{array}{l}\text { Source of } \\
\text { variation }\end{array}$ & df & Stat & $A$ & $E$ & gs & $C i$ & WUE & WUEi \\
\hline Species (S) & 1 & $\mathrm{~F}$ & 101.9 & 2.60 & 3.50 & 41.3 & 30.6 & 23.6 \\
& & $P$ & $<0.001$ & 0.115 & 0.070 & $<0.001$ & $<0.001$ & $<0.001$ \\
\hline Period (P) & 1 & $\mathrm{~F}$ & 140.4 & 9.10 & 12.7 & 70.5 & 27.4 & 16.4 \\
& & $\mathrm{P}$ & $<0.001$ & $<0.05$ & $<0.001$ & $<0.001$ & $<0.001$ & $<0.001$ \\
\hline $\mathrm{S} \times \mathrm{P}$ & 1 & $\mathrm{~F}$ & 0.44 & 5.60 & 8.30 & 5.80 & 5.10 & 9.50 \\
& & $\mathrm{P}$ & 0.510 & $<0.05$ & $<0.05$ & $<0.05$ & $<0.05$ & $<0.05$ \\
\hline Error & 36 & - & - & - & - & - & - & - \\
\hline Total & 39 & - & - & - & - & - & - & - \\
\hline
\end{tabular}




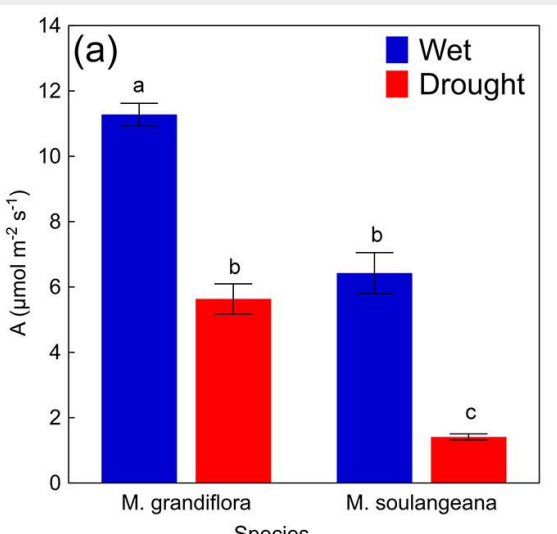

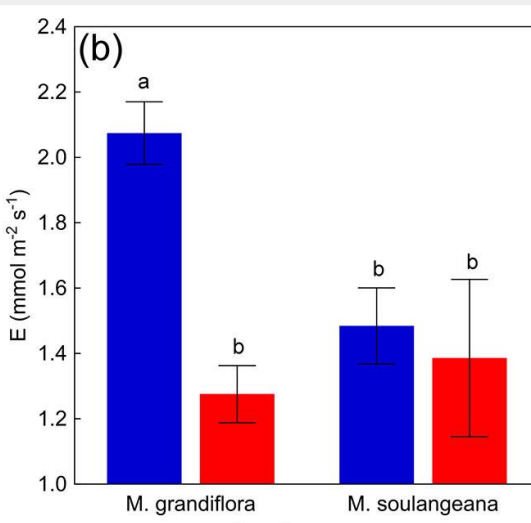

Species
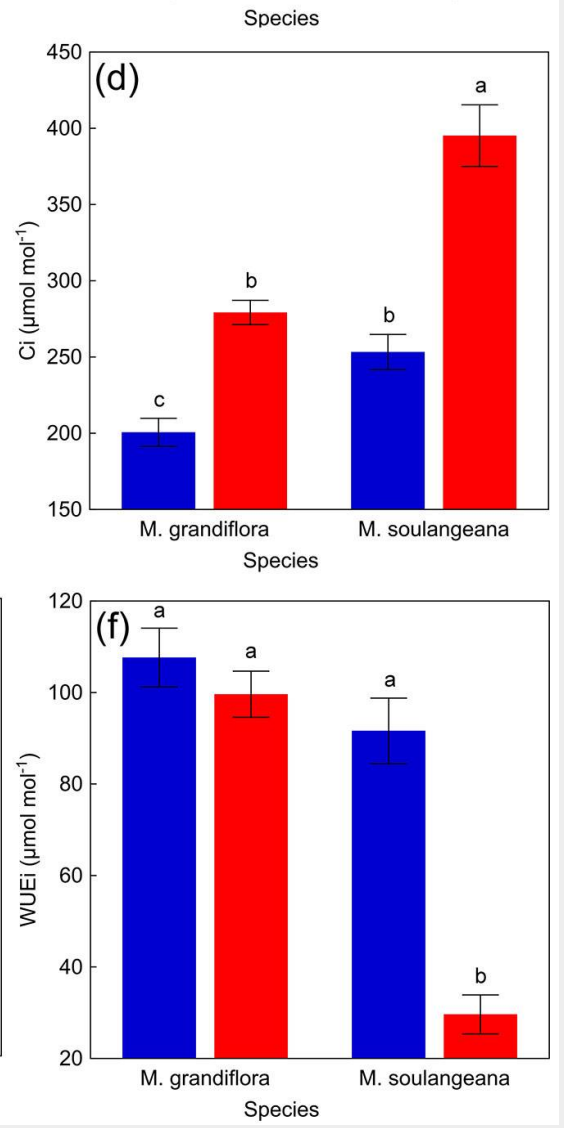

Fig. 2 - Leaf gas exchange parameters of $M$. grandiflora and $M$. soulangeana measured during the wet period and a drought period.

(a) net photosynthetic rate $\left(A, \mu \mathrm{mol} \mathrm{m} \mathrm{m}^{-2} \mathrm{~s}^{-1}\right)$;

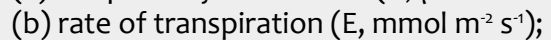

(c) stomatal conductance (gs, $\mathrm{mmol} \mathrm{m}^{-2} \mathrm{~s}^{-1}$ );

(d) intercellular $\mathrm{CO}_{2}$ concentration $(\mathrm{Ci}, \mu \mathrm{mol}$ $\mathrm{mol}^{-1}$ ); (e) water use efficiency (WUE, $\mu \mathrm{mol}$ $\left.\mathrm{mmol}^{-1}\right)$; (f) intrinsic water use efficiency (WUEi, $\mu \mathrm{mol} \mathrm{mol}^{-1}$ ). All values are presented as means \pm standard errors $(n=10)$. Different letters indicate significant differences $(\mathrm{p} \leq$ 0.05 ) between the values after Tukey's HSD test.
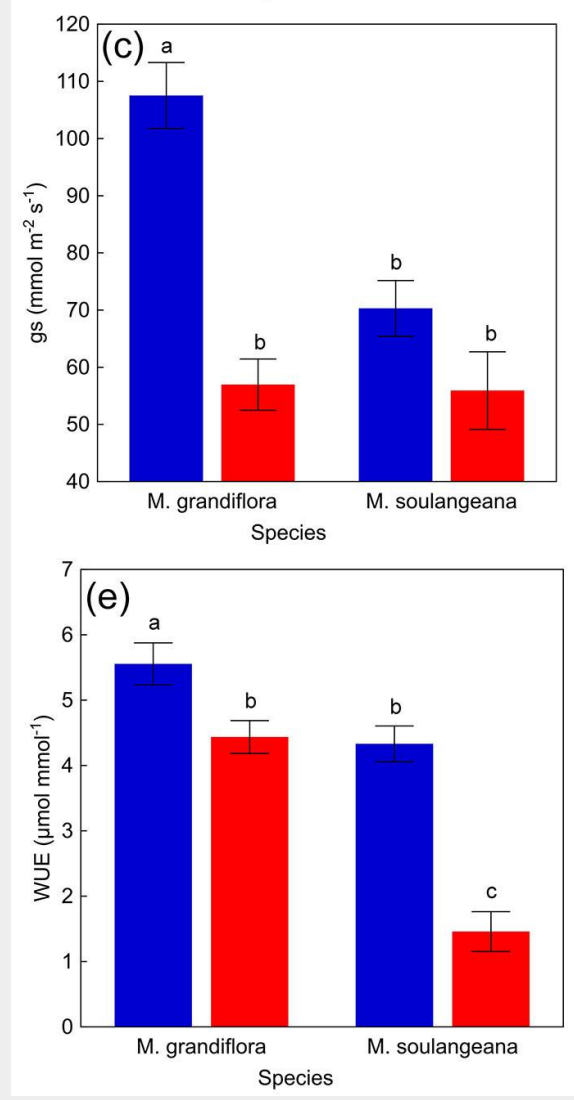

Tab. 3 - Results of two-way ANOVA showing the effect of species, period, and their interaction (species $\times$ period) on the observed parameters of chlorophyll a fluores-

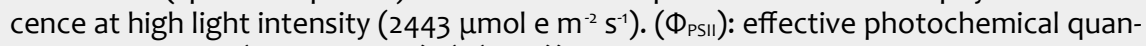
tum yield of PS II (relative units); ( $(\mathrm{NPQ})$ ): quantum yield of light-induced non-photochemical fluorescence quenching (relative units); ( $(\mathrm{NO})$ ): quantum yield of non-regulated heat dissipation and fluorescence emission (relative units); ((1-qP)/NPQ): index of susceptibility of leaves to light stress (relative units); (qP): coefficient of photochemical quenching (relative units); (ETRmax): maximum electron transport rate $\left(\mu \mathrm{mol} \mathrm{e} \mathrm{m}^{-2} \mathrm{~s}^{-1}\right) ;(\mathrm{df})$ : degrees of freedom.

\begin{tabular}{lcccccccc}
\hline $\begin{array}{l}\text { Source of } \\
\text { variation }\end{array}$ & df & Stat & $\Phi_{\text {PSII }}$ & Y(NPQ) & Y(NO) & $\begin{array}{c}(1-\mathrm{qP}) / \\
\text { NPQ }\end{array}$ & qP & ETRmax \\
\hline Species (S) & 1 & $\mathrm{~F}$ & 7.66 & 2.09 & 2.22 & 10.1 & 96.6 & 21.0 \\
& & $\mathrm{P}$ & $<0.01$ & 0.157 & 0.144 & $<0.01$ & $<0.001$ & $<0.001$ \\
\hline Period (P) & 1 & $\mathrm{~F}$ & 6.83 & 17.7 & 5.14 & 0.58 & 56.2 & 24.9 \\
& & $\mathrm{P}$ & $<0.05$ & $<0.001$ & $<0.05$ & 0.45 & $<0.001$ & $<0.001$ \\
\hline $\mathrm{S} \times \mathrm{P}$ & 1 & $\mathrm{~F}$ & 11.2 & 52.1 & 37.8 & 27.0 & 2.01 & 0.18 \\
& & $\mathrm{P}$ & $<0.01$ & $<0.001$ & $<0.001$ & $<0.001$ & 0.166 & 0.669 \\
& 36 & - & - & - & - & - & - & - \\
\hline Error & 39 & - & - & - & - & - & - & - \\
\hline Total & 39 & & - & & & & & \\
\hline
\end{tabular}

gas exchange parameters except for $A$. These results point to a different drought response of the examined species.

Drought significantly reduced $A$ and WUE, and increase $\mathrm{Ci}$ in both species (Fig. 2a, Fig. 2e, Fig. 2d). In detail, M. grandiflora decreased $E$ and gs (reduction of $38.2 \%$ and $47.0 \%$, respectively), whereas $M$. soulangeana maintained stable but overall low $E$ and gs values (reduction of only $6.1 \%$ and $7.6 \%$, respectively) during the drought period (Fig. 2b, Fig. 2c). M. grandiflora exhibited a higher decrease in $E$ and gs, while $M$. soulangeana showed generally weak performance under both measured periods. Furthermore, $M$. soulangeana exhibited significantly lower values of WUEi (reduction of $67.65 \%$ ) during drought in comparison to the wet period, while WUEi values in $M$. grandiflora were not significantly changed by severe drought (reduction of only $7.47 \%$ - Fig. 2f). 
Fig. 3 - Chlorophyll a fluorescence parameters generated by RLCs as a function of photosynthetically active radiation (PAR, $\mu \mathrm{mol}$ e $\mathrm{m}^{-2} \mathrm{~s}^{-1}$ ) measured in $M$. grandiflora and $M$. soulangeana during the wet period (blue lines) and the drought period (red lines). (a)

Effective photochemical quantum yield of PS II

( $\Phi_{\text {PSIII }}$, relative units); (b) quantum yield of lightinduced non-photochemical fluorescence quenching $(\mathrm{Y}(\mathrm{NPQ})$, relative units); (c) quantum yield of non-regulated heat dissipation and fluorescence emission ( $\mathrm{Y}(\mathrm{NO})$, relative units); (d) index of susceptibility of leaves to light stress ((1-qP)/

$N P Q$, relative units); (e) coefficient of photochemical quenching ( $\mathrm{qP}$, relative units); ( $f$ ) electron transport rate (ETR, $\left.\mu \mathrm{mol} \mathrm{e}^{-} \mathrm{m}^{-2} \mathrm{~s}^{-1}\right)$.
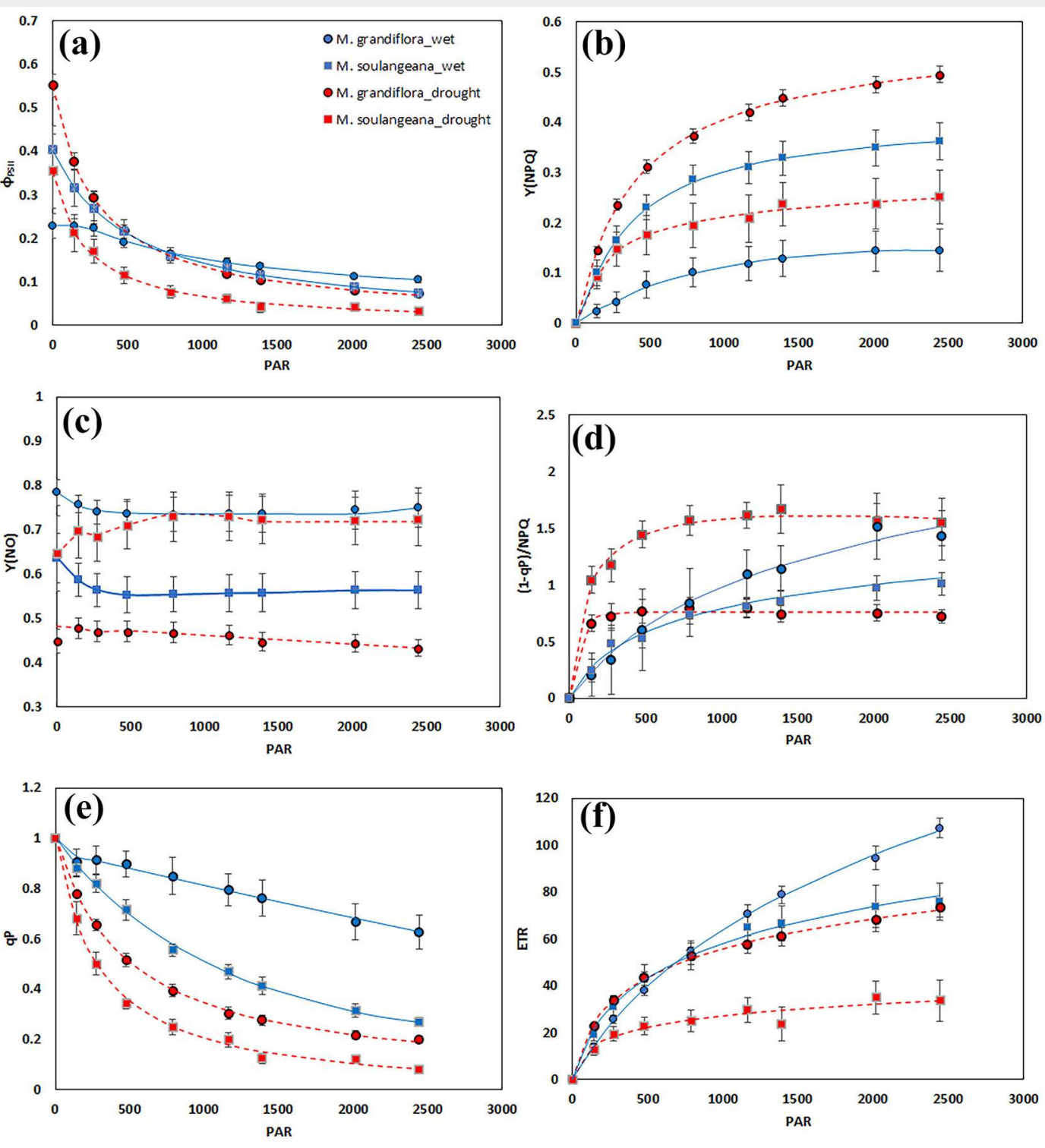

\section{Pulse amplitude modulated (PAM)}

\section{fluorescence}

The result of two-way ANOVA showed significant differences in $\Phi_{P S I I},(1-q P) / N P Q$, $\mathrm{qP}$ and ETRmax among the two magnolia species, while no significant changes were detected for $\mathrm{Y}(\mathrm{NPQ})$ and $\mathrm{Y}(\mathrm{NO})$ (Tab. 3). The analysis of the period (wet and dry) exhibited significant effect on all observed chlorophyll $a$ fluorescence parameters, except for (1-qP)/NPQ. Furthermore, the interaction of the species and period significantly influenced $\Phi_{\mathrm{PSII}} \mathrm{Y}(\mathrm{NPQ}), \mathrm{Y}(\mathrm{NO})$ and (1-qP)/NPQ parameters, while no significant effect was observed on qP and ETRmax.

Observing the RLC of $\Phi_{\text {PSII }}$, M. grandiflora showed higher values (until $477 \mu \mathrm{mol}$ e $\mathrm{m}^{-2}$ $\mathrm{s}^{-1}$ ) during drought compared to wet period, after which it has declined, while $M$. soulangeana exhibited lower values in drought, throughout all observed light intensities (Fig. 3a). Drought induced reduction of $\Phi_{\mathrm{PSII}}$ was observed in $M$. soulangeana, while no differences were found in $M$. grandiflora (Fig. 4a). In case of Y(NPQ), $M$. grandiflora showed higher values, while $M$. soulangeana lower values during drought (Fig. 3b). The values at high light intensity of RLC showed proportionally greater increase of $\mathrm{Y}(\mathrm{NPQ})$ during drought period in $M$. grandiflora, compared to the decrease for $M$. soulangena.

Furthermore, $\mathrm{Y}(\mathrm{NO})$ values of $M$. grandiflora were lower than in $M$. soulangeana during drought (Fig. 3c). According to the highest light intensities assessed, the reduction of $Y(N O)$ in $M$. grandiflora was statistically significant, while the increase in $M$. soulangeana was shown to be less significant (Fig. 4C). Considering (1-qP)/NPQ, $M$. grandiflora exhibited higher values (until $477 \mu \mathrm{mol}$ e $\mathrm{m}^{-2} \mathrm{~s}^{-1}$ ) during drought period compared to wet period, after which it has declined, while $M$. soulangeana showed increased values in drought over the irradiance range (Fig. 3d, Fig. 4d). A reduction of QP was observed in both magnolia species under severe drought as compared to the wet period (Fig. 3e, Fig. 4e). However, the reduction in values of the parameter $\mathrm{qP}$ in M. grandiflora during drought were similar to the values of $M$. soulangeana during wet period. Furthermore, drought reduced ETRmax in $M$. soulangeana, while in $M$. grandiflora higher values were found until

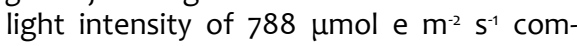
pared to wet period, after which it showed the opposite ranking (Fig. 3f). At high intensities, the reduction of ETRmax was found in both magnolia species, where $M$. grandiflora during drought and $M$. soulangeana during wet period showed the same range of values (Fig. 4f).

\section{Discussion}

The present study showed the adversely effects of the naturally occurring severe drought period on net photosynthetic rate $(A)$ in both magnolia species grown in urban environment. Even though A was significantly reduced in both species, $M$. grandiflora managed to maintain higher rates. This is advantageous on multiple counts, allowing an increased metabolic activity like the synthesis of sugars, amino acids, proteins, nucleic acids and lipids, all of them being essential for the growth and repair 


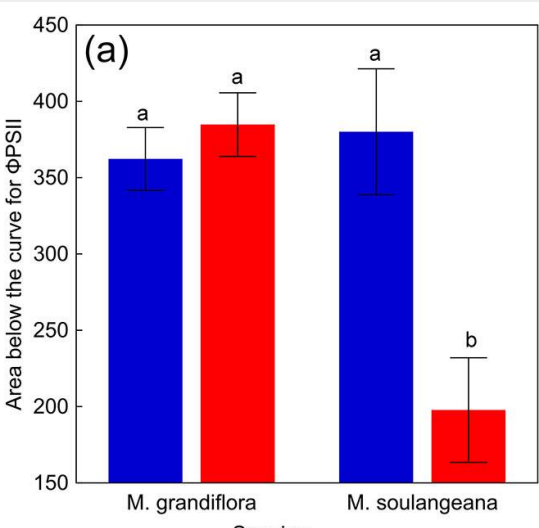

Species
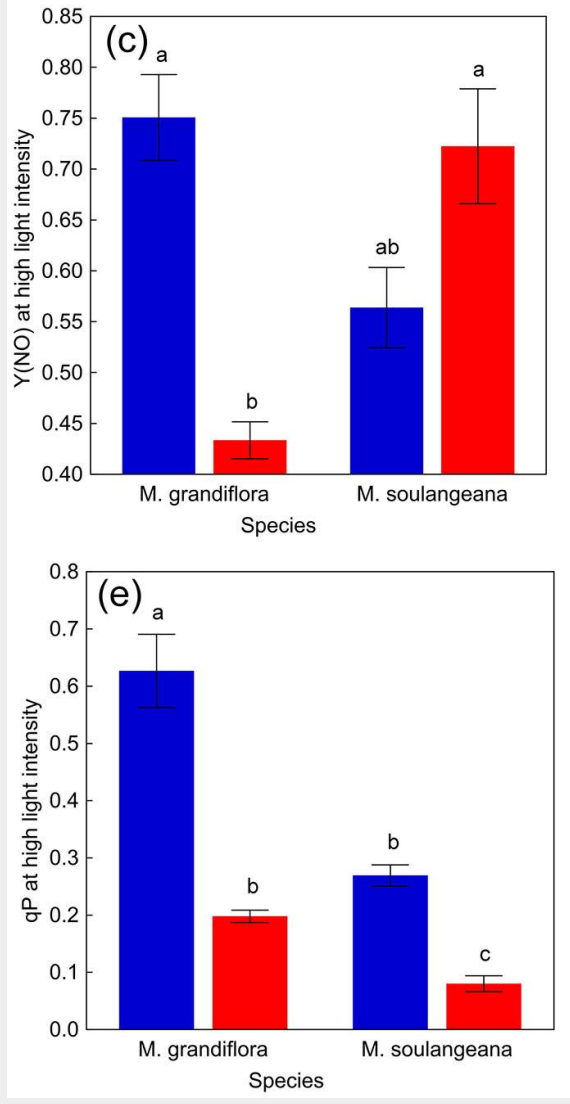

of damaged tissues (Percival et al. 2006). Similarly to our findings, many studies observed significantly reduced $A$ rates in urban areas, which are characterized by limited water availability (Percival et al. 2006, Osone et al. 2014) and sealed surfaces (Wang et al. 2019).

The reduction of $A$ under drought has been addressed to the protective mechanism of plants to avoid damage due to dehydration and hydraulic failure (Osone et al. 2014). During water shortage the roots are unable to penetrate in the deeper layers to find water resources and are left with low water supply, especially in urban areas where the soil is more compacted than in natural sites (Malmivaara-Lämsä \& Fritze 2003). The prompt response of stomata to environment constraints through stomatal regulation, the disruption in the $\mathrm{CO}_{2}$ supply caused by stomatal closure, is being addressed as the main cause of de-
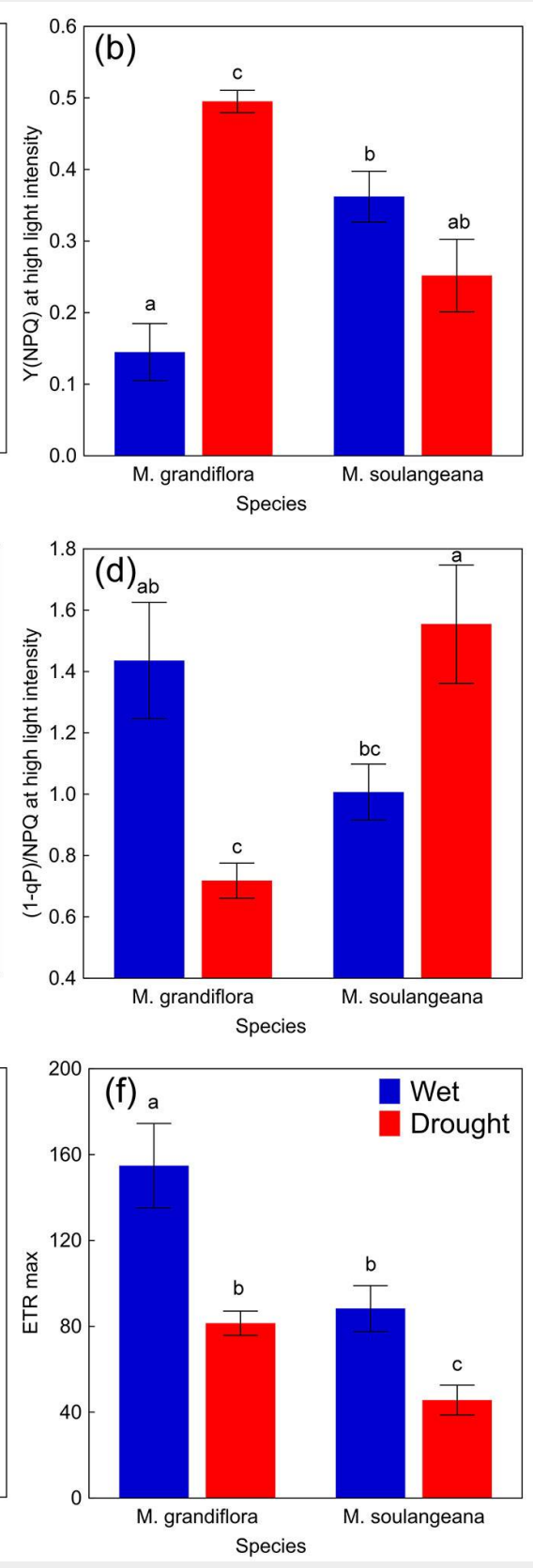

Fig. 4 - The parameters of chlorophyll $a$ fluorescence at high light intensity $(2443 \mu \mathrm{mol} e$ $\mathrm{m}^{-2} \mathrm{~s}^{-1}$ ) for $M$. grandiflora and $M$. soulangeana during the wet period and the drought period. (a) Effective photochemical quantum yield of PS II ( $\Phi_{\text {PSII }}$, relative units); (b) quantum yield of light-induced non-photochemical fluorescence quenching ( $\mathrm{Y}(\mathrm{NPQ})$, relative units); (c) quantum yield of non-regulated heat dissipation and fluorescence emission ( $\mathrm{Y}(\mathrm{NO})$, relative units); (d) index of susceptibility of leaves to light stress ((1-qP)/NPQ, relative units); (e) coefficient of photochemical quenching ( $q \mathrm{P}$, relative units); ( $\mathrm{f}$ ) maximum electron transport rate (ETRmax, $\mu \mathrm{mol}$ e $\mathrm{m}^{-2}$ $\left.\mathrm{s}^{-1}\right)$. All values are presented as means \pm standard errors $(n=10)$. Different letters indicate significant differences $(p \leq 0.05)$ between means after Tukey's HSD test. creased photosynthesis under mild to moderate drought (Xu et al. 2010).

$A$ reduction of gs and increase of $\mathrm{Ci}$ were observed during severe drought conditions for both magnolia species examined in the present study. As drought becomes more severe and long in time an increase in $\mathrm{Ci}$ values was also reported, evidencing the predominance of non-stomatal limitation to A (Briggs et al. 1986, Epron \& Dreyer 1990, Changhai et al. 2010). The reduction of $A$ under prolonged water shortage was related to diffusive (reduced mesophyll conductance) and metabolic (photochemical and enzymatic limitations) processes (Galmés et al. 2007). Metabolic limitations to $A$ were most frequently associated with the reduction of Rubisco activity and regeneration, resulting from reduced ATP or NADPH supply (regarded as photochemical limitation), or as the consequence of low enzymatic activity of the Polymerase Chain
Reaction cycle (Lawlor 2002). Prolonged periods of water deficit can also increase the oxygenase activity of Rubisco, reducing consequently the carboxylation efficiency, causing in such a way another commonly encountered non-stomatal limitation to $A$ (Medrano et al. 1997). In addition, the inhibition of $A$ might be attributed to the reduction of chlorophyll content, as a common symptom of oxidative stress under severe drought condition, resulting from pigment photooxidation and photosynthetic pigment degradation (Iturbe-Ormaetxe et al. 1998). A marked increase in $\mathrm{Ci}$ under more progressed drought period and the proportional decrease in $A$ rate was found to be less significant in comparison to the decline of gs in $M$. grandiflora, resulting in high WUE values (according to Pita et al. 2005). On the other hand, the net photosynthetic rate was more sensitive to soil water shortage than gs in $M$. soulangeana. 
Under the studied environmental constrain the significant decrease of WUEi in M. soulangeana was driven by a pronounced decline in $A$, while $M$. grandiflora maintained high WUEi values. Species characterized with higher WUEi values have specific water-saving strategy to avoid greater water losses and maintain higher assimilation rates, particularly important under the conditions of predicted climate changes (Brendel et al. 2008). Taking into account the effectiveness of WUEi as an indicator of drought sensitivity, the importance of identification of traits that could be utilized to improve WUEi and hence enhance drought adaptation in breeding programmes was noted (Stojnić et al. 2019).

$M$. grandiflora exhibited a higher ability to tolerate the prolonged period of drought compared to $M$. soulangeana, by maintaining greater values of $A$ and WUEi. This assumption is further supported by the slightly low rate of transpiration (E) in $M$. grandiflora, as noted for drought tolerant genotypes (Riaz et al. 2013). For instance, isohydric species show a lower water transpiration by retaining a greater amount of water, and then they are believed to be less vulnerable to drought (Basu et al. 2016). As the process of $E$ is facilitated through the stomata, stomatal control under drought condition is of key importance for a successful adaptation to environmental changes (Xu et al. 2010).

By maintaining higher $\Phi_{\text {PSII }}$ and ETRmax values during water shortage, $M$. grandiflora exhibited a higher efficiency in transporting electrons and potentially could fix more $\mathrm{CO}_{2}$ in comparison to $M$. soulangeana, as reported by Estrada et al. (2015) in drought-tolerant blueberry genotypes. In addition, high values of ETR parameter give a great advantage in the reduction of ROS in photosynthesis and in maintaining normal physiological functions (Liu et al. 2019). On the other hand, the decrease of $\Phi_{\mathrm{PSII}}$ in $M$. soulangeana during drought period indicated the physiological regulation of electron transport by increasing excitation energy quenching process in the PSII antennae, according to Ashraf \& Harris (2013). Furthermore, the decrease of Y(II) points to the decrease in the carboxylation efficiency, which affects the rate of consumption of ATP and NADPH (Queiroz-Alves et al. 2019).

Environmental stresses, such as water shortage and high light intensities, cause the saturation of electron transfer chain and the increase of the accumulation of proton, resulting in increase of $Y(N P Q)$ parameter (Wang et al. 2018). High values of $\mathrm{Y}(\mathrm{NPQ})$ under drought found in $M$. grandiflora could be addressed to the good ability of plants to mitigate the negative effects of the severe drought at the chloroplast level (Gonçalves et al. 2019). Consequently, the decline of $\mathrm{Y}(\mathrm{NPQ})$ in M. soulangeana indicated a loss of capacity to generate the trans-thylakoid proton gradient in chloroplast. A possible explanation for this phe- nomenon could be associated with the damage/decrease of PSI activity (Brestic et al. 2016). The simultaneous reduction of $\mathrm{Y}(\mathrm{NPQ})$ and increase of $\mathrm{Y}(\mathrm{NO})$ under drought in $M$. soulangeana further suggested the damage of PSII instead of the protective mechanism under the observed abiotic stress (Riva-Roveda et al. 2016). In accordance with these results, the increase of water deficit leads to damaging of the oxygen-evolving complex of PSIl (Riva-Roveda et al. 2016). The inhibited synthesis and accelerated degradation of D1 proteins causes further separation of electron transport complex QB and D1 within chloroplasts and results in the inability to accept electrons (Liu et al. 2019).

A pronounced decrease of $\Phi_{\mathrm{PSII}}$ and $\mathrm{qP}$ in $M$. soulangena suggested that the capability of photochemical conversion and the linear electron flux were both sensitive to the severeness and duration of drought (Wang et al. 2018). Beside a pronounced reduction of $\Phi_{\mathrm{PS} \|}$ and $\mathrm{qP}$, a sharper decline of ETR is a commonly observed characteristic of drought-susceptible genotypes (Sánchez-Reinoso et al. 2019), and reflects a reduced capability of the transport of electrons to fix $\mathrm{CO}_{2}$. The decrease of photosynthetic electron-transport rates along with lower trans-thylakoid $\mathrm{pH}$ gradient resulted in the accumulation of "excess photons" $((1-\mathrm{qP}) / \mathrm{NPQ})$ in $M$. soulangeana, suggesting that this species is more sensitive to light stress than M. grandiflora (Park et al. 1995). The observed reduction of $\mathrm{qP}$ coupled with the proportional increase $\mathrm{Y}(\mathrm{NPQ})$, showed that $M$. grandiflora was able to maintain the capacity to regulate dissipation of light energy under the observed drought. Moreover, it might be assumed that the xanthophyll's cycle of the examined species was efficient in providing a vent to the excess electrons flow generated for the increase in light intensity in the chloroplasts (De Sousa et al. 2017).

Our results highlight the overall higher drought-resistance of $M$. grandiflora compared to $M$. soulangeana. The sensitivity of $M$. soulangeana to drought is in line with the description provided for species selection in Citree, the urban tree database (https://citree.de/db-names.php?language= en). On the other hand, our findings revealed a drought-tolerant behavior in $M$. grandiflora that is contradictory to the information in the Citree database. In addition, our findings correspond with the studies reporting high drought tolerance of species and provenances from dry climates under water shortage conditions (Pšidová et al. 2015, Wang et al. 2017). The good adaptation potential of $M$. grandiflora to severe water deficits was assumed by Sjöman et al. (2018b) for urban street sites in North America and Europe.

\section{Conclusion}

This case study supports decision-making processes for the selection of trees in drought-affected urban areas by compar- ing two common ornamental tree species with similar aesthetic value. Measurements of leaf gas exchange parameters along with chlorophyll $a$ fluorescence showed $M$. grandiflora as a drought-tolerant species, while $M$. soulangeana exhibited susceptibility to drought, with a photosynthetic capacity sensitive to drought-induced stress. The decrease of $A$ in both magnolia species were related to non-stomatal factors, as evidenced by the decrease of ETRmax and a simultaneous increase of $\mathrm{Ci}$. Most of the observed parameters of leaf gas exchange, namely $E$, gs, Ci, WUE, and WUEi were proven to be highly sensitive to drought. In regard to chlorophyll a fluorescence, parameters related to the photochemical dissipation of light energy $\left(\Phi_{\mathrm{PSII}}\right)$ as well as associated with the heat dissipation of light energy (Y(NPQ), $\mathrm{Y}(\mathrm{NO})$ ) appear to be useful indicators for the selection of droughttolerant species, and are suggested for application in the assessment of plant responses in urban environments. Considering the predicted future climate change scenarios, $M$. grandiflora could be a good alternative to $M$. soulangeana for urban sites. The significance of the present study lies in the evaluation of the in situ physiological responses and selection of appropriate ornamental species for drought-prone urban environments.

\section{List of abbreviations}

A: net photosynthetic rate; Ci: intercellular $\mathrm{CO}_{2}$ concentration; $\mathrm{E}$ : rate of transpiration; ETR: electron transport rate; gs: stomatal conductance; $\Phi_{\text {PSII: }}$ : effective photochemical quantum yield of PS II; qP: coefficient of photochemical quenching; WUE: water use efficiency; WUEi: intrinsic water use efficiency; Y(NPQ): quantum yield of light-induced non-photochemical fluorescence quenching; $\mathrm{Y}(\mathrm{NO})$ : quantum yield of non-regulated heat dissipation and fluorescence emission; (1-qP)/NPQ: index of susceptibility of leaves to light stress.

\section{Acknowledgments}

This study was financed by the Ministry of Education, Science and Technological Development of the Republic of Serbia (contract number: 451-03-68/2020-14/200197). Furthermore, this work was carried out under the project "Establishing Urban FORest based solutions In Changing Cities" (EUFORICC), supported by the Ministry of Education, University and Research (MIUR) of Italy (PRIN 20173RRN2S).

\section{References}

Ashraf M, Harris PJC (2013). Photosynthesis under stressful environments: an overview. Photosynthetica 51 (2): 163-190. - doi: 10.1007/s1109 9-013-0021-6

Basu S, Ramegowda V, Kumar A, Pereira A (2016). Plant adaptation to drought stress. F100oResearch 5: 1554. - doi: 10.12688/f10oore search.7678.1

Brendel O, Le Thiec D, Scotti-Saintagne C, Bodénès C, Kremer A, Guehl JM (2008). Quantita- 
tive trait loci controlling water use efficiency and related traits in Quercus robur L. Tree Genetics and Genomes 4 (2): 263-278. - doi: 10.100 7/s11295-007-0107-z

Brestic M, Zivcak M, Kunderlikova K, Allakhverdiev SI (2016). High temperature specifically affects the photoprotective responses of chlorophyll b-deficient wheat mutant lines. Photosynthesis Research 130 (1-3): 251-266. doi: 10.1007/s11120-016-0249-7

Briggs GM, Jurik TW, Gates DM (1986). Nonstomatal limitation of $\mathrm{CO}_{2}$ assimilation in three tree species during natural drought conditions. Physiologia Plantarum 66 (3): 521-526. - doi: 10.1111/j.1399-3054.1986.tb05961.x

Changhai S, Baodi D, Yunzhou Q, Yuxin L, Lei S, Mengyu L, Haipei L (2010). Physiological regulation of high transpiration efficiency in winter wheat under drought conditions. Plant, Soi and Environment 56 (7): 340-347. - doi: 10.1722 1/220/2009-PSE

Chaves MM, Flexas J, Pinheiro C (2009). Photosynthesis under drought and salt stress: regulation mechanisms from whole plant to cell. Annals of Botany 103 (4): 551-560. - doi: 10.1093/a ob/mcn125

Cocozza C, De Miguel M, Pšidová E, Marino S, Maiuro L, Alvino A, Czajkowski T, Bolte A, Tognetti R (2016). Variation in ecophysiological traits and drought tolerance of beech (Fagus sylvatica L.) seedlings from different populations. Frontiers in Plant Science 7: 886. - doi 10.3389/fpls.2016.00886

Cocozza C, Perone A, Giordano C, Salvatici MC, Pignattelli S, Raio A, Schaub M, Sever K, Innes JL, Tognetti R, Cherubini P (2019). Silver nano particles enter the tree stem faster through leaves than through roots. Tree Physiology 39: 1251-1261. - doi: 10.1093/treephys/tpzo46

Cocozza C, Paoletti E, Mrak T, Zavadlav S, Levanič T, Kraigher H, Giovannelli A, Hoshika Y (2020). Isotopic and water relation responses to ozone and water stress in three oak species with different adaptation strategies. Forests 11 864. - doi: 10.3390/f11080864

Cvjetićanin R, Brujić J, Perović M, Stupar B (2016). Dendrologija. Udžbenik, Univerzitet u Beogradu-Šumarski fakultet, Beograd, Serbia, pp. 557. [in Serbian]

Dale AG, Frank SD (2017). Warming and drought combine to increase pest insect fitness on ur ban trees. PLoS One 12 (3): e0173844. - doi 10.1371/journal.pone.0173844

De Sousa CA, De Paiva DS, Casari RA, De Oliveira NG, Molinari HB, Kobayashi AK, Magalhães PC, Gomide RL, Souza MT (2017). A procedure for maize genotypes discrimination to drought by chlorophyll fluorescence imaging rapid light curves. Plant Methods 13 (1): 560. - doi: 10.1186/ s13007-017-0209-z

Eilers PHC, Peeters JCH (1988). A model for the relationship between light intensity and the rate of photosynthesis in phytoplankton. Eco logical Modelling 42 (3-4): 199-215. - doi: 10.10 6/0304-3800(88)90057-9

Epron D, Dreyer E (1990). Stomatal and non stomatal limitation of photosynthesis by leaf water deficits in three oak species: a compari son of gas exchange and chlorophyll a fluores cence data. Annals of Forest Science 47: 435 450. - doi: 10.1051/forest:19900503
Estrada F, Escobar A, Romero-Bravo S, GonzálezTalice J, Poblete-Echeverría C, Caligari PD, Lobos GA (2015). Fluorescence phenotyping in blueberry breeding for genotype selection under drought conditions, with or without heat stress. Scientia Horticulturae 181: 147-161. - doi: 10.1016/j.scienta.2014.11.004

Farquhar GD, Sharkey TD (1982). Stomatal conductance and photosynthesis. Annual Review of Plant Physiology 33 (1): 317-345. - doi: 10.1146/ annurev.pp.33.060182.001533

Flexas J, Niinemets U, Gallé A, Barbour MM, Centritto $M$, Diaz-Espejo A, Douthe C, Galmés J, Ribas-Carbo M, Rodriguez PL, Rosselló F, Soolanayakanahally R, Tomas M, Wright IJ, Farquhar GD, Medrano H (2013). Diffusional conductances to $\mathrm{CO}_{2}$ as a target for increasing photosynthesis and photosynthetic water-use efficiency. Photosynthesis Research 117 (1-3): 4559. - doi: 10.1007/s11120-013-9844-z

Früchtenicht E, Neumann L, Klein N, Bonal D, Brüggemann W (2018). Response of Quercus robur and two potential climate change winners Quercus pubescens and Quercus ilex to two years summer drought in a semi-controlled competition study: I. Tree water status. Environmental and Experimental Botany 152: 107117. - doi: 10.1016/j.envexpbot.2018.01.002 Galmés J, Medrano H, Flexas J (2007). Photosynthetic limitations in response to water stress and recovery in Mediterranean plants with different growth forms. New Phytologist 175 (1): 81-93. - doi: 10.1111/j.1469-8137.2007.02087.x

Genty B, Briantais JM, Baker NR (1989). The relationship between the quantum yield of photosynthetic electron transport and quenching of chlorophyll fluorescence. Biochimica et Biophysica Acta - General Subjects 990 (1): 87-92. doi: 10.1016/S0304-4165(89)80016-9

Genty B, Harbinson J, Cailly AL, Rizza F (1996). Fate of excitation at PS II in leaves: the nonphotochemical side. In: Proceedings of the " 3 rd BBSRC Robert Hill Symposium on Photosynthesis". University of Sheffield (UK) 31 Mar - 3 Apr. Department of Molecular Biology and Biotechnology, Western Bank, Sheffield, UK, pp. 28.

Giardi MT, Cona A, Geiken B, Kučera T, Masojidek J, Mattoo AK (1996). Long-term drought stress induces structural and functional reorganization of photosystem II. Planta 199 (1): 118-125. doi: 10.1007/BF00196888

Gonçalves KS, Alves LS, Paz VPD, Bandeira SDS (2019). Chlorophyll fluorescence of basil plants cultivated in a hydroponic system using treated domestic wastewater. Engenharia Agrícola 39 (3): 288-293. [online] URL: http://www.scielo. $\mathrm{br} / \mathrm{scielo}$.php?pid=S0100-69162019000300288\& script=sci arttext

Grimshaw J, Bayton R (2009). New trees: recent introductions to cultivation. Kew Publishing, Royal Botanic Gardens, Kew, UK, pp. 976.

IPCC (2007). Climate change 2007: the physical science basis. Contribution of working group I to the fourth assessment report of the Intergovernmental Panel on Climate Change. Cambridge University Press, Cambridge, UK and New York, NY, USA, pp. 996.

Iturbe-Ormaetxe I, Escuredo PR, Arrese-Igor C, Becana M (1998). Oxidative damage in pea plants exposed to water deficit or paraquat. Plant Physiology 116 (1): 173-181. - doi: 10.1104/ pp.116.1.173

Kendal D, Dobbs C, Lohr VI (2014). Global patterns of diversity in the urban forest: is there evidence to support the 10/20/30 rule? Urban Forestry and Urban Greening 13 (3): 411-417. doi: 10.1016/j.ufug.2014.04.004

Kleerekoper L, Van Esch M, Salcedo TB (2012). How to make a city climate-proof, addressing the urban heat island effect. Resources, Conservation and Recycling 64: 30-38. - doi: 10.1016/ j.resconrec.2011.06.004

Lawlor DW (2002). Limitation to photosynthesis in water-stressed leaves: stomata vs. metabolism and the role of ATP. Annals of Botany 89 (7): 871-885. - doi: 10.1093/aob/mcf110

Liu CC, Liu YG, Guo K, Zheng YR, Li GQ, Yu LF, Yang $R$ (2010). Influence of drought intensity on the response of six woody karst species subjected to successive cycles of drought and rewatering. Physiologia Plantarum 139 (1): 39-54. doi: 10.1111/j.1399-3054.2009.01341.x Liu ML, Chen BB, Li CM, Huang CZ (2019). Carbon dots: synthesis, formation mechanism, fluorescence origin and sensing applications. Green Chemistry 21 (3): 449-471. - doi: 10.1039/C8GC02 736F

Malmivaara-Lämsä M, Fritze H (2003). Effects of wear and above ground forest site type characteristics on the soil microbial community structure in an urban setting. Plant and Soil 256 (1): 187-203. - doi: 10.1023/A:1026227702403

Medrano H, Parry MAJ, Socias XDWL, Lawlor DW (1997). Long term water stress inactivates Rubisco in subterranean clover. Annals of Applied Biology 131 (3): 491-501. - doi: 10.1111/j.1744-7348. 1997.tbo5176.x

Moser A, Rötzer T, Pauleit S, Pretzsch H (2016). The urban environment can modify drought stress of small-leaved lime (Tilia cordata Mill.) and black locust (Robinia pseudoacacia L.). Forests 7 (3): 71. - doi: 10.3390/f7030071

Osmond CB (1994). What is photoinhibition? Some insights from comparisons of shade and sun plants. In: "Photoinhibition of Photosynthesis: from Molecular Mechanisms to the Field" (Baker NR, Bowyer JR eds). Bios Scientific Publishers, Oxford, UK, pp. 1-24.

Osone Y, Kawarasaki S, Ishida A, Kikuchi S, Shimizu A, Yazaki K, Aikawa S, Yamaguchi M, Izuta T, Matsumoto GI (2014). Responses of gas-exchange rates and water relations to annual fluctuations of weather in three species of urban street trees. Tree Physiology 34 (10): 1056-1068. - doi: 10.1093/treephys/tpuo86

Park Y, Chow WS, Anderson JM (1995). The quantum yield of photoinactivation of photosystem II in pea leaves is greater at low than high photon exposure. Plant and Cell Physiology 36 (6): 1163-1167. - doi: 10.1093/oxfordjour nals.pcp.a078863

Parmesan C (2006). Ecological and evolutionary responses to recent climate change. Annual Review of Ecology, Evolution and Systematics 37: 637-669. - doi: 10.1146/annurev.ecolsys.37.0913 05.110100

Percival GC, Keary IP, Sulaiman AH (2006). An assessment of the drought tolerance of Fraxinus genotypes for urban landscape plantings. Urban Forestry and Urban Greening 5 (1): 17-27. doi: 10.1016/j.ufug.2006.03.002

Pita P, Cañas I, Soria F, Ruiz F, Toval G (2005). 
Use of physiological traits in tree breeding for improved yield in drought-prone environments. The case of Eucalyptus globulus. Forest Systems 14 (3): 383-393. - [online] URL: http://citeseerx. ist.psu.edu/viewdoc/download?doi=10.1.1.718.41 52\&rep=rep1\&type=pdf

Pšidová E, Ditmarová L, Jamnická G, Kurjak D, Majerová J, Czajkowski T, Bolte A (2015). Photosynthetic response of beech seedlings of different origin to water deficit. Photosynthetica 53 (2): 187-194. - doi: 10.1007/s11099-015-0101-x Pšidová E, Zivčák $M$, Stojnić $S$, Orlović $S$, Gömöry D, Kučerová J, Ditmarováa K, Strelcová K, Bres tič M, Kalaji HM (2018). Altitude of origin influ ences the responses of PSII photochemistry to heat waves in European beech (Fagus sylvatica L.). Environmental and Experimental Botany 152: 97-106. - doi: 10.1016/j.envexpbot.2017.12. 001

Queiroz-Alves L, Leal A, Dalmolin C, Schaffer B, Mielke MS (2019). Photosynthesis and survival of young Carpotroche brasiliensis Endl. (Achariaceae) plants subjected to flooding. Forest Sci ence 65 (6): 670-674. - doi: 10.1093/forsci/fxzo 34

Rakhshandehroo M, Yusof MM (2014). Establishing new urban green spaces classification for Malaysian cities. In: Proceedings of the "IFLA Asia Pacific Congress 6". Kuching (Malaysia) 2830 Apr 2014, pp. 1-13.

Riaz A, Younis A, Taj AR, Karim A, Tariq U, Munir $S$, Riaz S (2013). Effect of drought stress on growth and flowering of marigold (Tagetes erecta L.). Pakistan Journal of Botany 45(S1): 123-131. [online] URL: http://www.researchgate. net/publication/259484411

Riva-Roveda L, Escale B, Giauffret C, Périlleux C (2016). Maize plants can enter a standby mode to cope with chilling stress. BMC Plant Biology
16 (1): 895. - doi: 10.1186/s12870-016-0909-y Sánchez-Reinoso AD, Ligarreto-Moreno GA, Restrepo-Díaz H (2019). Chlorophyll a fluorescence parameters as an indicator to identify drought susceptibility in common bush bean. Agronomy 9 (9): 526. - doi: 10.3390/agronomy 9090526

Schreiber U, Schliwa U, Bilger W (1986). Continuous recording of photochemical and non-photochemical chlorophyll fluorescence quenching with a new type of modulation fluorometer. Photosynthesis Research 10 (1-2): 51-62. - doi: 10.1007/BFoo024185

Sjöman H, Hirons AD, Bassuk NL (2018a). Improving confidence in tree species selection for challenging urban sites: a role for leaf turgor loss. Urban Ecosystems 21 (6): 1171-1188. - doi: 10.1007/s11252-018-0791-5

Sjöman H, Hirons AD, Bassuk NL (2018b). Magnolias as urban trees - a preliminary evaluation of drought tolerance in seven magnolia species. Arboricultural Journal 40 (1): 47-56. - doi: 10.1080/03071375.2017.1415554

Stojnić $S$, Kovačević B, Kebert M, Vaštag E, Bojović M, Nedić MS, Orlović S (2019). The use of physiological, biochemical and morpho-anatomical traits in tree breeding for improved water-use efficiency of Quercus robur L. Forest Systems 28 (3): e017. - doi: 10.5424/fs/201928315233

TIBCO Software Inc. (2017). Statistica (data analysis software system), version 13 . Web site. [online] URL: http://www.tibco.com/resources/da tasheet/tibco-statistica-big-data-analytics Van Kooten O, Snel JF (1990). The use of chlorophyll fluorescence nomenclature in plant stress physiology. Photosynthesis Research 25 (3): 147-150. - doi: 10.1007/BFo0033156 Vastag E, Kesić L, Karaklić V, Zorić M, Vuksanović
V, Stojnić S (2019). Physiological performance of sweetgum (Liquidambar styraciflua L.) and Norway Maple (Acer platanoides L.) under drought condition in urban environment. Poplar 204: 17-27. [online] URL: https://scindeks.ce on.rs/article.aspx?artid=0563-90341904017V

Vastag E, Cocozza C, Orlović S, Kesić L, Kresoja M, Stojnić S (2020). Half-sib lines of pedunculate oak (Quercus robur L.) respond differently to drought through biometrical, anatomical and physiological traits. Forests 11 (2): 153. - doi: 10.3390/f11020153

Vogt J, Gillner S, Hofmann M, Tharang A, Dettmann S, Gerstenberg T, Schmidt C, Gebauer H, Van De Riet K, Berger U, Roloff A (2017). Citree: a database supporting tree selection for urban areas in temperate climate. Landscape and Urban Planning 157: 14-25. - doi: 10.1016/j.landurbpl an.2016.06.005

Wang S, Callaway RM, Zhou DW, Weiner J (2017). Experience of inundation or drought alters the responses of plants to subsequent water conditions. Journal of Ecology 105 (1): 176-187. - doi: 10.1111/1365-2745.12649

Wang XM, Wang XK, Su YB, Zhang HX (2019). Land pavement depresses photosynthesis in urban trees especially under drought stress. Science of the Total Environment 653: 120-130. doi: 10.1016/j.scitotenv.2018.10.281

Wang Z, Li G, Sun H, Ma L, Guo Y, Zhao Z, Gao H, Mei $L$ (2018). Effects of drought stress on photosynthesis and photosynthetic electron transport chain in young apple tree leaves. Biology Open 7 (11): bio035279. - doi: 10.1242/bio.035279 Xu Z, Zhou G, Shimizu H (2010). Plant responses to drought and rewatering. Plant Signaling and Behavior 5 (6): 649-654. - doi: 10.4161/psb.5.6. 11398 